\title{
Maria, Mãe da Igreja em saída: Uma reflexão sobre a maternidade de Maria, do Concílio Vaticano II ao Decreto Ecclesia Mater no Magistério do Papa Francisco
}

Orientadora: Lúcia Pedrosa de Pádua

Mestrando: Thiago Azevedo Pereira

Área de Concentração: Teologia Sistemático-Pastoral

Linha de Pesquisa: Religião e Modernidade

Projeto de Pesquisa: "Qual Maria?" Figuras de Maria no desenvolvimento da teologia e no pontificado do Papa Francisco

Na contemporânea reforma do Papa Francisco em busca de uma "Igreja em Saída" e na instituição da celebração de "Maria, Mãe da Igreja", pode-se identificar em Maria um sinal da maternidade e da ternura da Igreja na nova evangelização.

Isso é perceptível através de uma redescoberta do papel da Virgem Maria no Mistério de Cristo e da Igreja, a partir de um caminho trilhado através da sagrada escritura, da tradição e do magistério, especialmente desenvolvido na mariologia eclesiotípica do Concílio Vaticano II e do Documento de Aparecida.

Palavras-chave: Mariologia. Mãe da Igreja. Igreja em saída. 